\title{
Causing Security Threat to Host State by Refugees: Context of Rohingya Refugees in Bangladesh
}

By Md. Zillur Rahman \& Dilshad Hossain Dodul Introduction-Bangladesh has been the host state of a large number of Rohingya refugees since August 2017. Rohingya, An ethnic minority group of Rakhine state, Myanmar, have been fleeing to Bangladesh after the Myanmar army started an ethnic cleansing on that area in august 2017. Since then, Bangladesh has been hosting around 1.1 million Rohingya refugees till now. In the first three months of the crisis, the majority arrived. During the first half of 2018, an estimated 12,000 people entered Bangladesh. Women and children are the vast majority in Bangladesh, and more than 40 percent are under 12 years of age (UNHCR 2020). As per the latest update of UNHCR, 860,243 Rohingya refugees are living in 187,534 households inside the camps (UNHCR 2020). After three years of this influx, Bangladesh is bearing the burden of Rohingya refugees and repatriation from Bangladesh is a far cry from reality. As (Mallick 2020) explain that, due to China and India's rising economic and strategic interests in repatriating the Rohingya refugees to the Rakhine State, Myanmar, foreign and regional organizations were unable to take any visible action. Organizations such as the United Nations, OIC, ASEAN, and other regional bodies have struggled to put pressure on Myanmar to take back Bangladeshi Rohingya refugees.

GJHSS-A Classification: FOR Code: 130205p

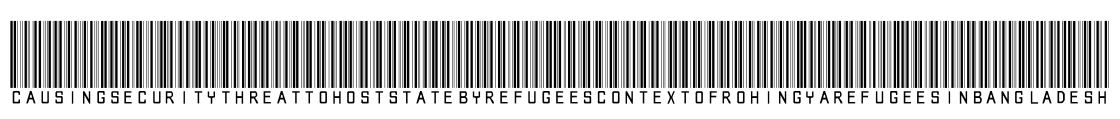

Strictly as per the compliance and regulations of:

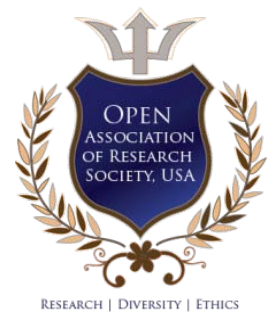

(C) 2020. Md. Zillur Rahman \& Dilshad Hossain Dodul. This is a research/review paper, distributed under the terms of the Creative Commons Attribution-Noncommercial 3.0 Unported License http://creativecommons.org/licenses/by-nc/3.0/), permitting all noncommercial use, distribution, and reproduction in any medium, provided the original work is properly cited. 


\title{
Causing Security Threat to Host State by Refugees: Context of Rohingya Refugees in Bangladesh
}

\author{
Md. Zillur Rahman ${ }^{\alpha}$ \& Dilshad Hossain Dodul ${ }^{\sigma}$
}

\section{INTRODUCTION}

2 angladesh has been the host state of a large number of Rohingya refugees since August 2017. Rohingya, An ethnic minority group of Rakhine state, Myanmar, have been fleeing to Bangladesh after the Myanmar army started an ethnic cleansing on that area in august 2017. Since then, Bangladesh has been hosting around 1.1 million Rohingya refugees till now. In the first three months of the crisis, the majority arrived. During the first half of 2018, an estimated 12,000 people entered Bangladesh. Women and children are the vast majority in Bangladesh, and more than 40 percent are under 12 years of age (UNHCR 2020). As per the latest update of UNHCR, 860,243 Rohingya refugees are living in 187,534 households inside the camps (UNHCR 2020). After three years of this influx, Bangladesh is bearing the burden of Rohingya refugees and repatriation from Bangladesh is a far cry from reality. As (Mallick 2020) explain that, due to China and India's rising economic and strategic interests in repatriating the Rohingya refugees to the Rakhine State, Myanmar, foreign and regional organizations were unable to take any visible action. Organizations such as the United Nations, OIC, ASEAN, and other regional bodies have struggled to put pressure on Myanmar to take back Bangladeshi Rohingya refugees. Repatriation of Rohingya people is a dream but the involvement of Rohingya people in different crimes is today's reality. (Star Editorial 2020) proved that Rohingya refugees are involved in many crimes such as murder, kidnapping, extortion and drug smuggling continue to burgeon. The statistical data shows that, In 2018, 208 criminal cases against Rohingya group members were filed. Last year, the number increased to 263. And 178 cases against the Rohingyas have already been filed in the first seven months of this year. According to the statement of law and enforcement organization, this is just the tip of the iceberg, according to law enforcers, as a vast number of crimes inside the camps, including murder, kidnapping, and sexual assault, go unreported. In these circumstances, the study is focusing on the threats that are posing by the Rohingya people in Bangladesh.

Author a: e-mail: zillur2010@gmail.com

\section{Research Question}

1. How Rohingya refugees are posing different level of threats on the local level.

2. How they are posing a national level security threat.

\section{Study Design}

This study followed a qualitative approach to understand the different levels of threats on the local level and national level from Rohingya refugees in Bangladesh. Researchers applied the Focus group discussion (FGD) method for qualitative data collection because this method initiates discussion and arguments within participants which bring out different views and perspective about a certain issue. The researcher uses purposive sampling method to select the member for focus group discussions as the individuals who were invited for the focus group discussion was the representative of the population of interest of this study. The researcher conducted two focus group discussions with a total of 29 participants in groups of 16 and 13 people respectively. One group includes the member from different law and enforcement forces and the participants of another group were local opinion leader from different sectors such as local government, Journalist, NGO workers. Focus groups interviewing generates a potentially much richer and more sensitive type of data which helps the researcher to find how Rohingya refugees are posing different levels of threats on the local level and national level.

\section{Literature Review}

The refugee crisis in Europe can no longer be interpreted as separate from the terrorist crisis following the attacks in Paris on 13 November 2015 (Nail 2016). This paper argues that under the circumstance of a double, but fully opposed, collection of crises internal to the nation-state, the image of the migrant has come to be seen as a possible terrorist in the West. (Nail 2016) Argues that a rapid change in focus between crises, the difference is that what was only implied in the European response to the Syrian refugees in response to the tragic attacks in Paris has become clear: that migration is understood to be a form in barbaric warfare that threatens the European Union. This research paper 
compares the refugee crisis with the terrorist crisis and makes it clear that Refugees in Europe are a burden for the nation-states and it is a potential security threat for the nations.

(Hangartner et al. 2019) uses a natural experiment in the Aegean Sea to investigate the influence of the refugee crisis on the perceptions, political preferences, and political involvement of indigenous people. Using distance to the Turkish coast as a method for exposure to the refugee crisis, (Hangartner et al. 2019) find that island residents who experience large and unexpected influxes of refugees become more hostile to asylum seekers, immigrants, and Muslims, and are more likely to encourage and advocate more restrictive asylum policies than natives on similar islands that receive fewer or no asylum seekers. This study also focuses on the mental state of host community and citizens of the different European nations and they find that in the issue of whether the government should limit the number of people to whom it grants asylum, the differences of opinion between Greek residents on exposed and non-exposed islands are as great as the differences of opinion between citizens of very restrictive and very liberal European countries.

(Ilgit and Klotz 2018) explained that this Syrian refugee crisis will create financial instability among Europe even if the Syrian civil war ends. He mentioned that continuing debates in Germany and across Europe indicate that, even if the Syrian civil war can be resolved, the increasing securitization is unlikely to ebb, as the multifaceted phenomenon of cross-Mediterranean migration will continue.

According to (Tharoor 2020) European governments are divided over what to do with asylum seekers in their midst and at their borders, and the open-arms policy of Merkel to Syrian refugees in 2015 inflamed nationalist governments in Central and Eastern Europe, thus prompting a conservative far-right uprising in the western part of the continent. This statement clarifies that Europeans are in a great dilemma with the refugee problem and now they are considering it as a security threat and the rise of nationalist political parties in Europe comply with this statement.

(Rahman 2010) argues that The Rohingya refugees, a group that migrated to Bangladesh after being displaced by Myanmar's military government, are among the most unfortunate ethnic minority groups in the world and have created a security dilemma for their host country's presence in Bangladesh. This study suggested that Bangladesh should not be ignorant of the human security of the Rohingya, considering its national security interests (Rahman 2010).

(Wolf 2014) argues that The Rohingya are accused of using their international network to distribute funds from like-minded organizations to Bangladeshi insurgent organizations even before the Rohingya influx in 2017. This paper point out the security concern of Bangladesh. This study finds that regardless of whether the Rohingya themselves pose actual or perceived threats to the host countries, Bangladesh's foreign relations will be strained as long as their issue of becoming stateless refugees remains unresolved (Wolf 2014).

(Mallick 2020) argues that the reparation process of Rohingya refugees will not happen in near future. The study finds that Myanmar is in the process of building Rohingya detention centers if they return to the state of Rakhine, which causes anxiety among Rohingya refugees living in Bangladesh. (Mallick 2020) point out the security threat and he explained that transnational militant groups such as al-Qaeda are likely to take advantage of the sufferings of Rohingya refugees after developing a solid network to stimulate religious identity politics and inspire group members to commit violent terror attacks in India, Bangladesh, Myanmar, Malaysia, and Indonesia.

Rohingyas are now involved in drug trafficking as well. According to The Department of Narcotics Control, there are more than five hundred Yaba selling camp spots in these two Upazilas. RAB and police sources say that Rohingya men smuggle Yaba and other drugs from Myanmar, which are subsequently supplied to women's businesses (Rahman 2019).

(Alsaafin 2018) tell the story of a Rohingya refuge who worked as a Yaba paddler in the Rohingya Refugee camp. For every 1,000 pills this person manages to travel from Kutupalong camp to Cox's Bazar, a popular tourist destination $40 \mathrm{~km}$ away, he is a Yaba carrier, earning 5,000 Bangladeshi Taka (\$60) and there are lots of Yaba paddler like him is living inside the camp.

The study shows that the refugee crisis is a potential security threat for any host nation. Different studies also showed that there could be different types of security threats and it could hamper the economic progress of a nation. Recent news reports explain that Rohingyas are involved in different types of crimes and previous studies helped us to understand that, there could be a security threat to Bangladesh amid the Rohingya refugee crisis. No recent studies are explaining the nature of security threats from Rohingya people. This study will help us to understand and develop a concept about the Rohingya refuge as a security threat to Bangladesh.

\section{Theoretical Framework}

Having stable government and geo-political importance among nations situated in the Horn of Africa, Kenya and Tanzania hosted a large number of refugees from other African countries in the 90s. A research article titles Refugee Realities: Refugee Rights versus State Security in Kenya and Tanzania, (Mogire 2009) stated 
that refugees were causing a threat to both of those nations at a different level. UN acknowledged three reasons as the causes of threat.

First, Mass Refugee Influx, especially which includes freedom fighters from the community seeking refuge, can pose a threat to the host nation. Second, Militarization of Refugee which includes not only violating host state's law, raising the tendency of criminal activities by refugees but also arms trading and trafficking. Last but not the least Refugees link to terrorism which includes terror attacks on the opponent group.

Three of these components are present in Bangladesh, home of more than a million Rohingya refugees, along with some other socio-political and economical facts.

\section{Findings and Data Analysis}

This study will analyze the data in two phases:

1. Findings from FGD with local representatives.

2. Findings from FGD with Local Law and enforcement officer from different wings.

1. FGD with representatives from a different sector of Cox's Bazaar

a) Threats on the local level

i. Environmental threat: Rohingya refugees are posing a big threat to the biodiversity of this area, especially reserve forest of this area have been destroyed largely to establish camps for refugees. According to the second respondent of FGD more than 4,000 acres of hills and forests in Ukhia and Teknaf of Cox's Bazar have been destroyed to make shelters and other resources and as a source of cooking fuel which is causing a big threat to these 'ecologically critical areas' of Bangladesh. He quoted a press release, published in 2018 by UNDP, which said 'From total forests of 1502 ha, about 793 ha of natural forest land has encroached. Around 3,000 to 4,000 acres $(1,200-1,600$ ha) of hilly land in the Teknaf-Ukhia-Himchari watershed area have been cleared of vegetation' (Environmental Impact, 2018). This report explored two key causes behind the forest destruction stating.

'The facts that nearly 6,800 tonnes of fuelwood are collected each month and each of the Rohingya families uses on an average 60 culms of Bamboo to construct their temporary shelters. Due to the indiscriminate hill cutting to provide shelters to the Rohingyas, the terrain of the hills have lost their natural setting, causing a potential risk of landslides.'

Another respondent emphasized the threat of decreasing groundwater level in that area which is caused due to the settlement of refugee camps. ' there are at least 10,000 water pumps are situated inside the camp and providing fresh water for more than one million people is causing dry well for irrigation in Teknaf area.'

ii. Economic Threat: The life expenses have been doubled in the last three years in Cox's Bazaar and Teknaf area, especially the price of daily necessities including foods and clothes are increasing rapidly. As respondent 4 said that people living in Cox's Bazaar did not have to depend on food supplies outside of Cox's bazaar before 2017. After the Refugee settlement, thousands of people including NGO workers and other professionals have started living in this area as hundreds of NGOs are working here to provide humanitarian aid to refugees which leads to dependency on the supply of food from outside Cox's bazaar and which resulted from increasing food prices.

House rents got high than ever due to sudden population growth in this area. As one of the respondents, who is also a representative of city office stated, 'local people are suffering from an imbalance between income and expenditure as income has not raised for most of the local people living in Cox's Bazaar, people from outside of the city are getting maximum benefits out of this crisis whereas local people are suffering due to high prices of daily necessities'.

Roads of Cox's bazaar have been destroyed entirely due to the high volume of transportation on the road. According to two respondents from a local college, the Transportation system of the city collapsed due to the establishment of hundreds of NGOs in this area which are using vehicles every day to go to Ukhia and Teknaf refugee camps. No development work regarding road construction is not working in the city because the number of transports using the roads of the city has been tripled since 2017.

People involved with the fishing business are replacing fishermen of the host community of Cox's Bazar with Rohingya refugees by helping them to make fake identity cards and recruit them as they work for less money than local fishermen.

Increasing rates of crime in Cox's bazaar area also is threatening the tourism business on which most of the business of Cox's bazaar depended. Cox's bazaar is one of the most popular places for tourists. However, since it became overpopulated because of the establishment of different organizations due to the Rohingya crisis and the cases or drug smuggling and robbing of tourists have been increased since 2017, this place is losing popularity to tourists which may affect the future of tourism business of this area.

iii. Possible Unemployment in Future: NGOs require volunteers who understand the Rohingya language to conduct aid work inside the camps as the local language of cox's bazaar is quite similar to the Rohingya language. The host community from 
Cox's Bazaar also demanded saving 70 percent of jobs, NGOs and, government offers, for them as compensation for their sacrifices. Thus a large number of local people, especially young people who are college students, are getting jobs as a volunteer and as women representatives from local city corporation stressed, there is a big chance that they will be unemployed when this crisis will be over or when the funds coming from NGOs from all over the world will be cut off.

Another crisis will be there with the students who are not finishing their graduation from college due to their present job as volunteers for NGOs. According to a respondent, a government official from the local community, the rate of graduation from college fallen to 30 percent in 2020 as most of the graduate-level students are already getting paid more than they expected and choosing not to complete their graduation. This tendency will also create unemployment shortly when the NGO will close their activity for Rohingya refugee camps.

iv. Cultural threat: The Establishment of Rohingya refugee camps harm socio-cultural issues of Cox's Bazaar, especially they have a negative perception about women working for NGOs in refugee camps, which they think, violation of their cultural norms and beliefs. According to most of the respondents attended to Focus Group Discussion, women doing jobs inside the camps as volunteers or as officials are violating norms of local society. For instance, most of the NGO workers, male or female, need to work inside the camps till afternoon and as refugee camps are far (one and a half hour driving) from Cox's Bazaar city, it gets dark when they reach their home which perceived negatively for women in that society. As some of the respondents, working with NGOs also encourages women to communicate with their male colleagues in a more free environment than before which, according to them, is developing a 'free mixing culture' in their society which goes against the values of the local community. Even, for women, getting training at hotels is e considered negatively in that society and as per the women respondents, getting married inside the community will be a struggle for female NGO workers, working inside the camps.

v. The threat of terrorism and extremism: Three of the respondents stressed the threat of increasing terrorist incidents in that area. A respondent, work for a local government, mentioned, most of the Rohingya refugees are radical and have an extreme mentality when it comes to religion and they use the internet to spread radicalism among not only among Rohingya refugees but also in the local community as many from the local community are connected with refugees through social media.
Rohingya people, fled to Bangladesh during the 90s, are mostly become a part of the local community and they have connections with refugees shifted to cox's bazaar since 2017. Thus, there is a chance of initiating religious tension in Cox's Bazar by Rohingya refugees.

With a population of 12,0000 , as one of the respondents specified, Rohingya refugees are double in number than Bangladeshi citizen in Cox's Bazaar and the impact of this fact is now visible in cox's bazaar as terrorism activities like killing over occupying lands and smuggling have been raised rapidly from last year. As one of the respondents, who works for an NGO, said, after the refugee settlement started in this area, drugs peddling incidents raised to its pick as refugees from Myanmar smuggle drugs to this country. He also alleged that refugees are selling arms to local perpetrators which have been creating unrest in the local community.

vi. Threat on local politics: As female representatives of local government informed, some dishonest politicians are helping refugees to get national identity cards of Bangladesh to create their vote bank in a different area. It was evident in recent local government elections that some politicians are giving refugees priority over national security to secure their position as the local government representative. Rohingya people are extremely religious, making them voters in this area will benefit political parties of the country which are based on religious values, as those respondents stated.

vii. Digital Threat: A Respondent working as a local correspondent of one of the national newspapers and a founder of a local NGO named 'Voice for Rohingya Repatriation' emphasized the uses of digital media and the internet by Rohingya refugees. according to the Rohingya people can pose the biggest threat to the security of Bangladesh by using the internet as activists of different political organizations of Rohingya people who have been demanding free land for them are living inside the camps and they use social media and digital messenger services to conduct their activism and to connect with other activists living in Rakhine state, Myanmar. As most of the Rohingya refugees are buying Bangladeshi sim cards illegally with the help of the host community, the government is not able to monitor their activities through the digital medium which might lead to tension between Myanmar and Bangladesh, in the future.

\section{b) Threats on National Level}

i. Mainstreaming with Bangladeshi citizens: One of the main objectives of the Bangladesh government to coordinate and monitor aid work in Rohingya refugee camps is to maintain the separation of 
Rohingya refugees from the mainstream, local community otherwise it will be a big struggle for Bangladesh to repatriate them to Myanmar. There are few facts given below which are making this process of separation difficult for the government.

Rohingya refugees with newborn children are trying to do birth registration of their children in Bangladesh with the help of some people from the local community in an exchange for money. One of the female local government representatives informed that some local family planning officials are selling birth registration certificates and some people from the host community are pretending to be fake parents of Rohingya children to get the certificates and thus a good number of them will become the part of the local community.

According to another female local government representative, Due to their extreme religious belief, most of the Rohingya people consider birth control methods anti-Islamic and are very resistant to using these methods so the birth rate is very high inside the camps. As they tend to follow shariah law, having more than one wife is justified in their community which is another reason besides the high birth rate among them. With this birth rate, as she stated, soon the number of refugees, which already have been more than double than the population of the host community, will be so large to live inside the present camp area. This crisis of places already have been leading government to occupy green fields or empty places that belonged to the host community until now which is another cause behind the fact that a lot of Rohingya people are getting the chance to blend in with the local community.

Another respondent, a local NGO worker emphasized the fact that a large number of Rohingya people are creating fake passports from local passport offices, and brokers who send migrant laborers to Middle Eastern countries, illegally, are helping them to do so. As he mentioned, poor people from the local community are certifying refugees seeking new passports as their family members to law and enforcement members in exchange for money. As a lot of Rohingya refugees have family members living around the world, especially countries in the Middle East like Saudi Arabia, they do not even ask for job security from brokers instead they just want to leave Bangladesh at any cost and that is why sometimes brokers even send them with fake passports or fake job papers. As one of the respondents, a journalist, support this fact mentioning that this is the reason behind the Saudi Arabia government recently asked Bangladesh to give the legal passport to fifty thousand Rohingya refugees living there illegally.

ii. Occupying a part of the country: Most of the respondents, attending the discussion agreed to the fact that Rohingya refugees are going to initiate a movement or fight for free land in near future and as they are now the majority according to the population in Cox's Bazaar, they might want this piece of Bangladesh as their land which is a big threat for Bangladesh's geographical existence.

One of the respondent, working in the tourism business, said it is not an unknown fact now for the local community of Cox's Bazaar that some of the activists of 'Al Yakin', an organization, wants free Rakhine state for Rohingya people are living inside camps and they are making arms, using those for internal clashes and selling them to people of local communities, sometimes. Many Rohingya leaders and their followers are also using the internet to create an opinion about having free land for their own which is not necessarily in Rakhine state, Myanmar. So, The possibility for Rohingya people to become a national threat for Bangladesh should not be unnoticed.

Risks of leaking information about border security: Teknaf, where a big Rohingya settlement is established and thus a working place for many international organizations, is one of the most important border areas for Bangladesh. As two of the respondents stated, when the crisis started, many foreign aid workers had come to Bangladesh without valid visas, even law and enforcement officials found few officials working for NGOs, causing tension or having suspicious activities in camp areas. So, the possibility of the existence of foreign agents, leaking important border information for other countries, is something to think about. especially, mapping the position of border guards or leaking information about the activities of law and enforcement institutions of Bangladesh can cause a big threat to the country.

2. FGD with Local Law and enforcement officer from different wings.

\section{a) Threats on Local Level}

i. Increasing the number of crime incidents: Cox's bazaar has become one of the biggest hubs of selling Yaba (a special kind of drug) in South Asia since Rohingya refugee started coming here, a respondent who works for the Intelligence team, said in the discussion. According to him, smuggling drugs is one of the ways of income for Rohingya refugees and at least one member, especially the younger one, from every refugee family is involved in drug peddling. Another respondent working for Cox's bazaar police informed that local people are giving the fishing job to Rohingyas as they charge less money which gives Rohingya people a way to smuggle drugs, especially Yaba from Myanmar. As this drug is so small, sometimes they carry it inside the fish. According to one of the sub-inspector of police, he, while doing his duty inside Rohingya camps, has found that most of the teenage 
refugees own expensive mobile phones. While being asked, they answered that most of them have relatives working in countries in the Middle East and these phones are gifted by them. As the respondent mentioned, most of the refugees arrested by police for robbing local people or tourists or smuggling drugs are young and they earn money by doing these illegal businesses.

Some of the human traffickers from the local community as well as from refugee camps have been trafficking women and girls from the beginning of the crisis in 2017 and Law and enforcement groups working in Cox's bazaar are struggling a lot to control this crime. As one of the Member from Bangladesh Ansar said that it is not hard to find families inside the camps who want their girl children to be trafficked to other countries, especially selling parentless young girls has been a common incident since the influx began. Sometimes, even the family members are selling their children to traffickers or women, especially those who are widows with two, three children with no income sources are trying to be trafficked or fled to other countries with the help of human traffickers. These incidents are impacting the law and order of the local community hugely, especially the movement of human traffickers have increased in this area which is affecting local people as well.

Having Rohingya refugees in Cox's Bazaar affecting the security of tourists coming to this area. As this is one of the most popular tourist areas of the country, the economy of local people is largely dependent on the tourism-related business. However, as a respondent from tourist police said, refugees, are hugely involved in robbing tourists in less popular beaches of the city, especially the incidents of hurting tourists while robbing mobile phone and money from them have been increased recently which make this city unsafe for tourists. As he mentioned, cox's bazaar is popular for its longest beach but for security reasons, tourist police have to narrow the option of roaming in beaches after dark for tourists which hurts tourism in this area.

ii. Social Damages: The freedom of movement of local community people has been hampered because of the surveillance and checking system by Law and enforcement groups due to mitigating the crises raised because of the Rohingya settlement in Cox's Bazaar. As one of the respondents from the Ansar department said there is a check box in every entrance and exit point of the city and law and enforcement check identity cards of all who pass those points which often cause unwanted situations with people from the local community.

A sub-inspector of police who was the only female respondent of this FGD said that women of this are more involved in consuming as well as peddling drugs than before 2017. According to her, she has to deal with too many cases recently with women drug peddlers, sometimes who are refugees. Women who have their husbands working as migrant workers in other countries are mostly customers of Yaba and peddlers are using Rohingya women sometimes to reach that group of consumers because there is a social restriction of meeting women in private for male outsiders. These cases led consumers to sell drugs to their peer group which causing a big social dilemma for the local community.

Prostitution business has also been getting larger in this area after the Rohingya influx began. As one of the tourist police mentioned, maximum low and priced hotels and lodge are using Refugee women as prostitutes to attract tourists. Refugees, particularly women without husbands and young women are very unsafe inside camps and they are desperate to blend in with the mainstream population at any cost which giving opportunities to human traffickers as well as brokers to use them for prostitution.

iii. Additional Pressure on different wings of law and enforcement group: Law and enforcement of the area of Refugee camps are too busy to deal with legal crises related to refugees that often problems related to the local community are being ignored. One of the respondents from Bangladesh police emphasized this issue saying that sometimes they have to compromise their duty to local people who are Bangladeshi citizens because Rohingya people are double in amount and they are causing too much tension in this area that law and enforcement are often struggling to control the situation.

iv. Threats on National level: Officials of different wings of Law and enforcement group, working to control the refugee-related crises in the area of Cox's Bazaar have specified few problems which have been initiated by Rohingya refugees and which might cause threat on national security.

v. Blending with the local community: As duty officials of check posts mentioned, Rohingya refugees get a pass from their block leaders (Majhi) to leave camps and go to hospitals of the city in the name of getting advanced medical services and sometimes do not return to the camps. As discussed earlier, they have been used by some people of local communities to do illegal jobs who help them to stay inside the city and provide fake national identity cards. Fake birth registration or NID is available in some computer service giver shops in the city which are so similar to original ones that often law and enforcement officials struggle to identify fake ones without digital assistance.

Another respondent from tourist police said that the maximum of the Rohingya refugees have brought a huge amount of gold with them instead of money and 
they also get financial assistance from their relatives living outside Bangladesh. Local people, especially poor people, often marry them in exchange for money to provide NID to them. As Rohingya people are already the majority according to the amount of population in that area, including them in mainstream society will cause a threat to the national security of Bangladesh in the future. The possibility of demanding this piece of land as a free state for Rohingya people cannot be ignored based on some of their recent activities, as the respondent mentioned.

If this situation arises in near future, as one of the assistant police super said, they will get help not only from Myanmar but also from some countries in the Middle East. Even, shifting a big amount of Rohingya refugees to Bhashan Chor (an island in the Bay of Bengal) may sound like a solution for reducing pressure on Cox's Bazaar but it may cause another threat to the geographical security of Bangladesh because in near future Rohingya people might try to occupy that big island to make their dream of a free state, possible. Recently, as the ASP said, Rohingya refugees, who are living in Bangladesh since the 90s, demanded citizenship in a mass gathering which means if they stay long in this part of the country, they will create tension in this part of the country in the future and as border district, this is not a good sign for our national security.

vi. Digital Threat: As discussed earlier, officials of Law and enforcement have also addressed the fact that they use the sim from Myanmar as they find the network in Teknaf and through those activists of the terrorist group in Teknaf refugee camps are connected their mates living in Myanmar which might cause unrest in that area.

\section{Vil. Conclusion}

There is a common conception about refugees is that they are the victim and oppressed by a specific community of their state. However, the fact that they can cause a security threat to their host nation is often ignored in the discussion of academia. Recently, there is a sharp growth of terror incidents in Cox's Bazaar and Teknaf where Rohingya refugee camps are situated and according to the findings from this research, the government, as well as policymakers of Bangladesh, should reconsider the fact that a large number of refugees can produce potential security threat to the country.

\section{References Références Referencias}

1. Alsaafin, Linah. 2018. '"I Carry Yaba to Survive': Rohingya and Bangladesh's Meth Trade. "Retrieved October 4, 2020 (https://www.aljazeera.com/ features/2018/8/19/i-carry-yaba-to-survive-rohingyaand-bangladeshs-meth-trade).
2. Hangartner, Dominik, Elias Dinas, Moritz Marbach, Konstantinos Matakos, and Dimitrios Xefteris. 2019. "Does Exposure to the Refugee Crisis Make Natives More Hostile?" American Political Science Review 113(2): 442-455.

3. Legit, Asli, and Audie Klotz. 2018. "Refugee Rights or Refugees as Threats? Germany's New Asylum Policy." The British Journal of Politics and International Relations 20(3): 613-31. DOI: 10.1177/ 1369148118778958.

4. Mallick, Abdullah Hossain. 2020. "Rohingya Refugee Repatriation from Bangladesh: A Far Cry from Reality." Journal of Asian Security and International Affairs 7 (2): 202-26. DOI: 10.1177/2347797020 938983.

5. Maguire, Edward. 2009. "Refugee Realities: Refugee Rights versus State Security in Kenya and Tanzania." Transformation 26(1): 15-29.

6. Nail, Thomas. 2016. "A Tale of Two Crises: Migration and Terrorism after the Paris Attacks." Studies in Ethnicity and Nationalism 16(1): 158-167.

7. Rahman, Abdur. 2019. "More than 500 Yaba Selling Spots at 34 Rohingya Camps | Banglatribune. Com." Bangla Tribune. Retrieved October 4, 2020 (https://en.banglatribune.com/country/news/68605/ More-than-500-yaba-selling-spots-at-34-Rohingya).

8. Rahman, Utpala. 2010. "The Rohingya Refugee: A Security Dilemma for Bangladesh." Journal of Immigrant \& Refugee Studies 8(2): 233-39. DOI: 10.1080/15562941003792135.

9. Star Editorial. 2020. "Desperate Rohingyas Turning to Crimes." The Daily Star. Retrieved October 4, 2020 (https://www.thedailystar.net/editorial/news/ desperate-rohingyas-turning-crimes-1952077).

10. Tharoor, Ishaan. 2020. "Analysis | Europe Can't Wish Away Syrian Refugees." Washington Post, March 2.

11. UNHCR. 2020. "Rohingya Emergency." UNHCR. Retrieved October 10, 2020 (https://www.unhcr.org/ asia/rohingya-emergency.html).

12. Wolf, Siegfried O. 2014. "The Rohingyas Crisis: A Security Perspective from Bangladesh." 